\title{
KEPEMIMPINAN WALI NAGARI PEREMPUAN (FEMALE LEADERSHIP) DI NAGARI SULIT AIR KECAMATAN X KOTO DIATEH KABUPATEN SOLOK PERIODE 2014 - 2020
}

\author{
Akbar Karim \\ Jurusan Ilmu Politik, Fisip, Universitas Andalas \\ Email : akbarkarim9@gmail.com
}

\begin{abstract}
Abstrak
Kepemimpinan sangat penting dalam organisasi, karena dalam proses interaksi untuk mencapai tujuan, dimana orang yang ada di dalam organisasi tersebut membutuhkan seseorang yang dapat mengkoordinasikan, mengarahkan dan memudahkan. Kepemimpinan seseorang bisa dilatih dan dipelajari untuk meningkatkan kemampuan seseorang tersebut menjadi pemimpin yang efektif. Adapun tujuan dari penelitian ini adalah untuk menjelaskan gaya kepemimpinan dari seorang perempuan (Female Leadership) yang terpilih menjadi seorang Wali Nagari di Nagari Sulit Air Kecamatan X Koto Diateh Kabupaten Solok serta perbedaan gender dalam kepemimpinan perempuan (Female Leadership) dengan kepemimpinan laki-laki. Berdasarkan hasil penelitian yang dilakukan peneliti mendapatkan bahwasannya sebagai pemimpin perempuan di Nagari Sulit Air, Alex mampu membawa perubahan terhadap Nagari tersebut dengan menggunakan kepemimpinan situasional dimana pendekatan ini menekankan bahwa kepemimpinan terdiri dari dimensi perintah dan pemberian dukungan, masing-masing dimensi itu diterapkan pada situasi tertentu.
\end{abstract}

Kata Kunci : Kepemimpinan; Pendekatan Situasional; Wali Nagari

\begin{abstract}
Leadership is very important in organizations, because in the process of interaction to achieve goals, where people in the organization need someone who can coordinate, direct and facilitate. One's leadership can be trained and learned to improve one's ability to become an effective leader. The purpose of this study is to explain the leadership style of a woman (Female Leadership) who was chosen to be a Wali Nagari in Nagari Sulit Air Kecamatan X Koto Diateh, Kabupaten Solok and gender differences in female leadership (Female Leadership) with male leadership. Based on the results of research conducted by researchers found that as a female leader in Nagari Difficult Air, Alex was able to bring changes to Nagari by using situational leadership where this approach emphasizes that leadership consists of command and support dimensions, each dimension applied to a particular situation.
\end{abstract}

Keywords : Leadership; Situational Approach; Wali Nagari

\section{PENDAhUluan}

Pada saat ini telah terjadi perubahan paradigma dalam kehidupan politik dan ketatanegaraan di Indonesia yaitu dari sistem otoritarian kepada sistem demokrasi dan dari sistem sentralistik kepada sistem otonom. Perubahan paradigma penyelenggaraan pemerintahan dari sistem sentralistik menuju sistem desentralisasi ${ }^{1}$ menyebabkan terbukanya

\footnotetext{
1 Desentralisasi mengandung pengertian pelimpahan kekuasaan lebih jauh kedalam berbagai arena pemerintahan
} distrik maupun perkotaan. Menurut Undang-Undang No. 5 Tahun 1974, pengertian desentralisasi adalah 
ruang bagi daerah untuk mengurus dan mengatur rumah tangganya sesuai dengan karakteristik masing-masing. Atas dasar itu daerah-daerah bisa saja mengambil kebijakan pembenahan sistem pemerintahan sesuai dengan kondisi sosial budaya dan aspirasi masyarakat di daerah.

Menurut Utang Rosyidin (2010) adapun tujuan utama dari desentralisasi tersebut dari segi politik adalah untuk menyalurkan partisipasi politik di tingkat daerah untuk terwujudnya stabilitas politik nasional. Serta untuk menjamin bahwa pembangunan akan dilaksanakan secara efektif dan efisien di daerah-daerah dalam rangka mewujudkan kesejahteraan sosial. Demikian otonomi daerah atau desentralisasi akan membawa sejumlah manfaat baik bagi masyarakat di daerah maupun pemerintah nasional.

Di Provinsi Sumatera Barat perubahan paradigma ${ }^{2}$ penyelenggaraan pemerintahan sebagaimana yang di maksud UU No. 23 Tahun 2014 tentang Pemerintahan Daerah, telah di manfaatkan untuk menata kembali pemerintahan Nagari sebagaimana mestinya berdasarkan adat basandi syarak syarak basandi kitabullah ${ }^{3}$ dengan dikeluarkanya Perda No. 7 Tahun 2018 tentang Nagari ${ }^{4}$. Dalam sejarah politik di Indonesia dan negara berkembang pada umumnya, keterlibatan atau peranan perempuan dalam bidang politik dipandang terlambat. Stigma $^{5}$ yang ada pada masyarakat bahwa perempuan dalam posisi domestik $^{6}$ dianggap

penyerahan urusan pemerintahan dari pusat kepada daerah. Pelimpahan wewenang tersebut semata-mata bertujuan untuk mewujudkan suatu pemerintahan yang lebih efektif dan efisien. Hasil dari pelimpahan wewenang tersebut adalah terbentuknya daerah otonom atau otonomi daerah, yaitu adanya kebebasan pemerintah daerah tertentu dalam mengatur dan mengurus kepentingannya sendiri.

2 Istilah paradigma cenderung merujuk kepada dunia pola pikir atau pun teknis penyelesaian masalah yang dilakukan oleh manusia. Istilah yang satu ini pertama kali diperkenalkan oleh seorang ilmuan bernama Thomas Kuhn melalui buku buatannya yang berjudul The Structure of Scientific Revolution. Pradigma berkaitan erat dengan prinsip - prinsi dasar yang menentukan berbagai macam pandangan manusia terhadap dunia sebagai bagian dari sistem bricoluer.

3 Adat basandi syarak, syarak basandi kitabullah merupakan suatu filsafat Minangkabau yang dalam bahasa Indonesia berarti "adat berdasarkan agama, agama berdasarkan kitab Allah". Agama dalam hal ini bisa diartikan sebagai agama Islam karena agama sebagian besar orang Minangkabau adalah Islam. Sementara itu, kitab Allah yang dimaksudkan adalah Alquran. Jika dikaji lebih dalam lagi, filsafat ini mengandung makna yang sangat dalam. Secara umum, filsafat ini menjelaskan bahwa Minangkabau merupakan sebuah budaya atau suku yang berlandaskan kepada Allah swt. Selain itu, adat dan agama pun tidak bisa dipisahkan. Keduanya senantiasa berjalan beriringan.

4 Hal ini juga dilatar belakangi oleh pemikiran bahwa sistem Pemerintahan Nagari dipandang efektif guna menciptakan ketahanan agama dan budaya berdasarkan tradisi dan sosial budaya masyarakat Sumatera Barat.

5 Stigma juga dipergunakan dalam istilah "stigma social" yaitu tanda bahwa seseorang dianggap ternoda dan karenanya mempunyai watak yang tercela, misalnya seorang bekas narapidana yang dianggap tidak layak dipercayai dan dihormati. Stigma dapat mendorong seseorang untuk mempunyai prasangka pemikiran, perilaku dan atau tindakan oleh pihak pemerintah, masyarakat, pemberi kerja, penyedian layanan kesehatan, teman sekerja, para teman dan keluarga. Stigma membuat pembatasan pada Pendidikan, pekerjaan, perumahan dan perawatan kesehatan. Stigma dapat dialami sebagai rasa malu atau bersalah atau secara luas dapat dinyatakan sebagai diskriminasi. Hal ini dapat menyebabkan penurunan percaya diri, kehilangan motivasi, penarikan diri dari kehidupan sosial, menghindari pekerjaan, interaksi dalam kesehatan dan kehilangan perencanaan masa depan.

${ }^{6}$ Domestik adalah sesuatu yang berhubungan dengan atau mengenai permasalahan dalam negeri. Arti domestik juga bermakna segala sesuatu yang bersifat kerumahtanggaan. Hal ini berarti istilah domestik mencakup segala sesuatu yang masuk dalam ruang lingkup internal dalam negeri atau dalam rumah tangga. 
sebagai salah satu hal yang mengakibatkan perempuan terlambat berkiprah dalam dunia politik. Sebagai salah satu indikatornya adalah jumlah perempuan yang memegang jabatan publik masih sangat sedikit.

Seperti yang dikatakan Utami (2001), mewujudkan kesetaraan gender ${ }^{7}$ adalah salah satu upaya mewujudkan demokratisasi, karena dengan kesetaraan gender akan membuka peluang serta akses bagi seluruh masyarakat dari segala lapisan untuk ikut serta melakukan proses demokratisasi itu sendiri. Upaya mewujudkan kesetaraan gender sejauh ini telah dilakukan oleh cukup banyak pihak. Namun realita yang terjadi dalam masyarakat masih banyak praktek ketidakadilan gender dalam berbagai aspek kehidupan yang kebanyakan dialami oleh perempuan. Kenyataan itu pada gilirannya menghambat cita-cita demokratisasi itu sendiri, karena terdapat diskriminasi di dalamnya.

Jendrius (2017) mengatakan dalam gender, terjadi pembedaan peran, wilayah, status dan pensifatan. Dalam peran, umumnya masyarakat masih menganggap peran laki-laki sebagai pekerja produktif yang menghasilkan nilai ekonomis/uang, sedangkan perempuan merupakan pekerja reproduktif. Masyarakat Minang secara tradisional mereka hidup berkelompok dalam suatu ikatan genealogis ${ }^{8}$ dan teritorial berdasarkan pemerintahan yang otonom dan diatur dengan hukum adat yang berlaku. Nagari di Sumatera Barat hadir sebelum datangnya Belanda ke Indonesia. Nagari di lambangkan sebagai "republik mini" yang diperintah secara demokratis oleh masyarakat Nagari. Sistem Pemerintahan Adat tersebut hilang secara de jure semenjak diberlakukannya UU No. 5 Tahun 1979 mengenai bentuk pemerintahan kecil yaitu desa, kebijakan ini membuat Nagari terpecah ke dalam bentuk desa di mana secara struktural dan legal formal sedikit demi sedikit mengubah Nagari meskipun

\footnotetext{
7 Menurut Mosser (1989) gender adalah "perbedaan laki-laki dan perempuan yang dititik beratkan kepada perilaku, harapan, status dan peranan setiap insan laki-laki dan perempuan yang ditentukan oleh struktur sosial di mana ia berada". Peranan gender timbul sebagai akibat perbedaan persepsi masyarakat terhadap laki-laki dan perempuan yang menentukan bagaimana seorang laki-laki atau seorang perempuan berfikir, bertindak dan berperasaan. Artinya, dalam kehidupan bersosial, manusia tidak hanya dipandang dari perbedaan biologis saja, namun juga dari peranannya sebagai laki-laki dan sebagai perempuan, di mana peranan tersebut di "buat", di "tentukan" oleh masyarakat diwarnai oleh budaya, norma, dan tata nilai yang berlaku di masyarakat tersebut.

8 Genealogi berasal dari kata dasar gene, yaitu plasma pembawa sifat-sifat keturunan. Geneologi berarti ilmu yang mempelajari masalah keturunan. Ia berarti juga saling bergantung dua hal, yaitu muda berasal dari yang tua. Misalnya tulisan Jawa berasal dari perkembangan (baca : keturunan) abjad Pallawa. Tulisan Pallawa berasal dari konteks ini yang dimaksud genealogi ialah yang menyangkut hubungan keturunan individu. Peletak dasar genealogi sebagai ilmu ialah J. Ch. Gatterr (1727-1799), kemudian Q. Lorerirensa menerapkan dalam penulisan ilmiah (1898). Dalam kenyataan sejarah genealogi sangat penting semenjak manusia memasuki zaman sejarah, khususnya menyangkut masalah tahta. Perhatikan misalnya prasasti Yupa dari Muarakaman di Kutai. Prasasti itu dengan jelas memberitakan Genealogi Mulawarman dengan leluhurnya: Kudungga. Prasasti Canggal (732M) melukiskan genealogi Sanjaya dan leluhurnya.
} 
undang-undang yang berkaitan dengan desa secara tegas hendak mempertahankan nilai-nilai lokal.

Saat dikeluarkan UU No. 22 Tahun 1999 tentang Desentralisasi dimana pada saat ini UU No. 23 Tahun 2014 tentang Pemerintahan Daerah dan memberikan hak otonomi kepada daerah untuk mengatur pemerintahannya sendiri sehingga dimanfaatkan oleh pemerintahan Provinsi Sumatera Barat yang mengembalikan bentuk pemerintahan lokal kembali ke bentuk Nagari dengan mengeluarkan Perda No. 9 Tahun 2000 dan dilengkapi dengan perda Perda No. 2 Tahun 2007 dimana pada saat ini ada Perda No.7 Tahun 2018 tentang Nagari. Ketika diberlakukannya UU No. 5 Tahun 1979 tersebut Nagari mengalami transformasi bukan hanya ke bentuk desa, melainkan lembaga-lembaga di dalam Nagari juga ikut bertransformasi. Pada saat desa dihapuskan dan Nagari dihidupkan kembali melalui Perda No. 2 Tahun 2007 yang sudah di perbarui menjadi Perda No. 7 Tahun 2018 tentang Nagari, semestinya lembaga pemerintahannya juga ikut berubah. Namun, dalam kenyataannya tidak demikian. Dalam kasus pemerintahan Nagari ini, kebijakan dan intervensi pemerintah terhadap pemerintahan Nagari merupakan salah satu faktor yang menyebabkan timbulnya perubahan sosial melalui cara-cara yang struktural dalam masyarakat.

Di Sumatera Barat, pembicaraan representasi ${ }^{9}$ perempuan di sektor publik tentu relevan, karena masyarakat dikenal memiliki adat dan budaya bercorak demokratis. Adat matrilineal juga memuliakan posisi kaum perempuan, tidak hanya karena penarikan garis keturunan (nasab) dari garis ibu, tetapi juga ketentuan tradisional bagi perempuan untuk memiliki dan menguasai harta pusaka. Dalam cerita-cerita tradisional, seperti di tambo, kaba dan legenda, peran perempuan Minang dalam kehidupan sosial, termasuk politik, juga tergambarkan. Kaba Mande Rubiah (Ibu Rubiah) sebagai Bundo Kanduang, misalnya, jelas merepresentasikan posisi penting perempuan dalam kehidupan sosial di Ranah Minang (Nurwani Idris, 2010: 167)

Tendensi ${ }^{10}$ kepemimpinan formal di Minangkabau selama ini, mulai di tingkat provinsi, kabupaten, Nagari dan desa (masa akhir Orde Baru) yang selalu didominasi lakilaki. Politisi perempuan hanya dalam peran substitusi. Di pihak lain, secara umum, pandangan masyarakat lokal masih patriarkis ${ }^{11}$. Seakan yang layak dan harus menjadi

\footnotetext{
${ }^{9}$ Representasi adalah sebuah proses ataupun keadaan yang ditempatkan sebagai suatu perwakilan terhadap sebuah sikap/perbuatan dari sekelompok orang/golongan tertentu di dalam sebuah lingkingan. Representasi merupakan sebuah proses sosial yang berhubungan dengan pola hidup dan budaya masyarakat tertentu yang memungkinkan terjadinya sebuah perubahan konsep-konsep ideologi dalam bentuk yang konkret. Hal ini dapat dilihat melalui pandangan-pandangan hidup kita terhadap beberapa hal seperti: pandangan hidup tentang seorang wanita, anakanak dan yang lainnya.

10 Tendensi adalah satu set atau satu disposisi untuk bertingkah laku dengan suatu cara tertentu ; atau suatu sikap keberpihakan/kecendrungan terhadap objek permasalahan tertentu.

11 Patriakis adalah sebuah sistem sosial yang menempatkan laki-laki sebagai pemegang kekuasaan utama dan mendominasi dalam peran kepemimpinan politik, otoritas moral, hak sosial dan penguasaan properti.
} 
pemimpin sosial dan politik itu adalah laki-laki. Konstruksi sosial ini berkembang luas di tengah masyarakat, termasuk masa reformasi. Keterpilihan perempuan dalam pemilihan wali Nagari di beberapa Nagari, dalam batas tertentu, mampu mematahkan mitos tersebut.

Gejala baru di Era Reformasi yaitu terpilihnya beberapa Wali Nagari perempuan di beberapa Nagari. Pemilihan Wali Nagari dengan sistem langsung ternyata dapat membuka kesempatan kepada perempuan untuk tampil lebih jauh di panggung politik Nagari-Nagari, yang selama ini didominasi laki-laki. Seperti terpilihnya Jurniwati sebagai Wali Nagari di Nagari Tigo Balai, Kecamatan Matur, Kabupaten Agam, Alex Suryani di Nagari Sulit Air, Kecamatan X Koto Diateh, Kabupaten Solok, Linda Sri Ningsih di Nagari Lalang Panjang Inderapura Kecamatan Air Pura Kabupaten Pesisir Selatan. Pemilihan Wali Nagari ini dilaksanakan pada tahun yang berbeda dimana Wali Nagari ini berhasil mengalahkan calon Wali Nagari lain yang semuanya adalah laki-laki, selain itu Wali Nagari yang terpilih samasama menjadi Wali Nagari perempuan pertama di Nagari tersebut. Di tengah gencarnya sorotan atas rendahnya partisipasi dan kiprah kepemimpinan politik perempuan di Era Reformasi, masyarakat Nagari tersebut ternyata mampu menampilkan Wali Nagari perempuan sebagai hasil pilihan rakyat.

Melalui tugas dan wewenang Wali Nagari tidak memungkinkan bagi perempuan untuk menjadi Wali Nagari. Akan tetapi pada umumnya laki-laki selalu mendominasi untuk menjadi pemimpin baik itu dipusat maupun didaerah. Ini terlihat berbeda pada pemilihan Wali Nagari di Sulit Air pada Tahun 2014 yang dimenangkan oleh perempuan dengan suara mutlak. Ini tentu menjadi fenomena yang menarik untuk dikaji karena dilatar belakangi dengan kebudayaan daerah dimana Sulit Air terletak di daerah Minangkabau, serta gaya kepemimpinan perempuan yang tidak terlepas dari gender.

Nagari Sulit Air dipimpin oleh seorang Wali Nagari perempuan yang bernama Alex Suryani untuk menjabat periode 2014 - 2020 serta menjadi sejarah untuk Nagari tersebut dipimpin oleh seorang Wali Nagari perempuan. Alex merupakan istri dari Firdaus Kahar yang merupakan Wali Nagari periode 2003 - 2006. Alex dibesarkan di Nagari Sulit Air tepatnya di Jorong Koto Gadang dimana pendidikan terakhir Alex adalah S1 Pendidikan Bahasa Inggris di STKIP PGRI Sumatera Barat. Sebelum melanjutkan pendidikan S1 alex pernah bekerja diperusaan Jepang sebagai operator untuk koordinator dalam pembuatan peti kemas di Tanjung Priok serta alex sudah pernah bekerja diperusahaan-perusahaan asing lainnya seperti perusahaan Amerika, Jerman dan lain sebagainya.

Pada tanggal 22 November $2014 \mathrm{Hj}$ Alex Suryani secara resmi dilantik sebagai Wali Nagari di Lapangan Medan Nan Bapaneh Nagari Sulit Air. Seperti yang dituliskan pada akun Facebook Nagari Sulit Air :

"Hj. Alex Suryani, SPd terpilih jadi Wali Nagari Sulit Air 
Pemilihan Wali Nagari yang biasa disingkat Pilwana di Nagari Sulit Air - Solok Sumatera Barat telah usai dilakukan pada siang hari tanggal 1 November 2014 dengan hasil terpilihnya Srikandi Sulit Air Ibu Hj. Alex Suryani, SPd yang kesehariannya adalah isteri dari mantan Wali Nagari periode 2008-2014 yang lalu yaitu Bpk. H. Firdaus Kahar.

Beliau unggul di 6 TPS yang digelar dari sebanyak 12 TPS di Sulit Air yang mempunyai 13 jorong itu. Ada 1 TPS yang merupakan gabungan dari 2 Jorong yaitu TPS 1 yang menggabungkan warga Jorong Batu Galeh dan Jorong Sarikieh.”

Dalam penelitian sebelumnya yang dilakukan oleh (1) Jumiati Sasmita dan Said As'ad Raihan (2013), penelitiannya menemukan Pria dan wanita sebenarnya memiliki kemampuan yang sama menjadi seorang pemimpin yang efektif. Perbedaan gender tidaklah menjadi masalah, karena yang paling penting adalah memiliki efektivitas dan kredibilitas dalam memimpin sehingga dapat mencapai tujuan organisasi. Walaupun ada sedikit perbedaan potensi kepemimpinan di antara pria dan wanita, namun keunggulan dan kelemahan potensi kepemimpinan wanita dan pria merupakan hal yang saling mengisi. Pentingnya wanita mengubah mindset dengan cara lebih menyadari bahwa dirinya memiliki kesempatan yang sama untuk bisa menjadi seorang pemimpin di tempat bekerja. (2) Yayan Hidayat dan Iwan I. Febrianto (2016), mengatakan pasca desentralisasi, keberadaan Nagari Pariangan sebagai institusi politik justru kehilangan legitimasi politisnya untuk digerakkan oleh masyarakat sendiri. Bahkan dalam beberapa keadaan, Nagari Pariangan menjadi kendaraan politik elit lokal untuk mencapai kepentingan politik dan ekonomi berskala nasional.

Selanjutnya (3) Yasril Yunus (2017), dari tulisannya Yasril bercerita bahwa reformasi telah mencapai akarnya, kesadaran konstitusi desa diramalkan akan mendorong proses reformasi berbasis otonomi daerah. UU Desa telah menjabarkan secara sistematis dan mampu memberikan hak-hak pada setiap desa di Indonesia, khususnya Nagari di Minangkabau untuk mengembangkan potensi-potensi yang ada di Nagari. (4) Jendrius (2017), menemukan dalam hal gender, proses desentralisasi di Minangkabau menarik dan merupakan bidang studi yang penting, karena Minangkabau adalah masyarakat matrilineal terbesar di dunia. Studi ini menunjukkan bahwa perempuan mendapatkan dukungan dari kelompok kerabat mereka ketika berpartisipasi dalam politik lokal karena kekerabatan adalah modal sosial bagi partisipasi politik perempuan.

Dari pemaparan permasalahan yang terjadi pada saat ini maka munculah rumusan masalah dalam penelitian ini yaitu ketika perempuan menduduki posisi kepemimpinan, seperti yang terjadi di Nagari Sulit Air, Kecamatan X Koto Diateh, Kabupaten Solok, bagaimana gaya kepemimpinan dari seorang perempuan (Female Leadership) yang terpilih menjadi seorang Wali Nagari di Nagari tersebut? 
Transformasi dari desa ke Nagari banyak mengalami disfungsi kelembagaan baik secara struktur maupun kewenangan tumpang tindih lembaga adat dan lembaga pemerintahan desa yang membuat posisi lembaga adat terlemahkan, khususnya dalam kewenangan mengurusi peraturan masyarakat Nagari. Perubahan dalam struktur pemerintahan dan peraturan yang berlaku dalam masyarakat tersebut bercorak nasional sehingga menggeser dominasi posisi adat-istiadat murni Nagari. Dampaknya, selain melemahkan struktur adat juga menyebabkan hilangnya corak adat-istiadat di Nagari. Dominasi negara terhadap Nagari ini membuat posisi adat menjadi termarjinalkan sehingga berdampak pada kemurnian adat-istiadat yang ada di Nagari, ditunjukan dengan tidak berfungsinya ninik mamak, alim ulama dan cerdik pandai yang merupakan tokoh masyarakat Nagari serta melemahnya lembaga adat yang disebut dengan tali tigo sapilin, tungku tigo sajarangan sebagai simbol adat minang. Pada akhirnya, tidak tampak lagi yang dimaksud dengan formula "adat basandi syarak, syarak basandi kitabullah" yang membuat Minang lebih terlihat sebagai heterarki - suatu masyarakat atau sistem politik yang didasarkan bukan pada hierarki tapi pada pluralitas dan multiplitas bentuk-bentuk politik yang lebih kecil dan berulang-ulang (Hadler, 2010, p. xiii).

Pada penelitian tentang kepemimpinan Wali Nagari perempuan kali ini peneliti menggunakan pendekatan situasional. Dalam buku Peter (2016) yang membahas tentang pendekatan situasional mengatakan bahwa pendekatan kepemimpinan yang paling diakui adalah pendekatan situasional, yang dikembangkan oleh Hersey dan Blanchard (1969a) dengan didasarkan pada Reddin (1967) teori gaya manajemen 3D. Pendekatan situasional telah diperbaiki dan diperbaharui beberapa kali sejak peluncuran pertama. Kepemimpinan situasional berfokus pada kepemimpinan pada situasi di sekitar pemimpin. Prinsip pada teori ini adalah situasi yang berbeda menuntut jenis kepemimpinan yang berbeda. Dapat diketahui bahwa untuk menjadi pemimpin yang efektif harus menyesuaikan gaya dengan tuntutan dari situasi yang berbeda.

Pendekatan situasional digambarkan dalam model yang dikembangkan oleh Blanchard yang disebut sebagai model Kepemimpinan Situasional II (Bagan 1). Model ini adalah perluasan dan penyempurnaan dari model kepemimpinan situasional awal yang dikembangkan oleh Hersey dan Blanchard (1969a). Dinamika dari kepemimpinan situasional paling bisa dipahami ketika membagi model SLII menjadi dua bagian: gaya kepemimpinan dan tingkat perkembangan pengikut. 


\section{Bagan 1. Kepemimpinan Situasional}

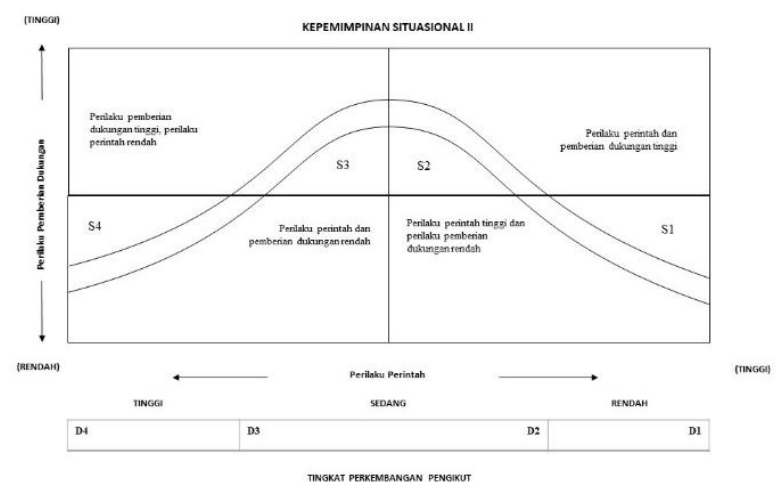

Sumber: Northouse, Peter G. 2016. Kepemimpinan: Teori dan Praktik Edisi Keenam.

\section{Jakarta Barat: Indeks Permata Puri Media. Hlm 96}

Model SLII menggambarkan bagaimana perilaku kepemimpinan perintah dan pemberi dukungan mengombinasikan empat gaya kepemimpinan yang berbeda itu. Seperti yang ditunjukan oleh tanda panah (lihat Bagan 1) di bagian bawah dan sisi kiri model tersebut, perilaku perintah tinggi di kuadran S1 dan S2 serta rendah di kuadran S3 dan S4, serta perilaku pemberi dukungan tinggi di S2 dan S3 serta rendah di S1 dan S3.

\section{METODE PENELITIAN}

Penelitian ini menggunakan pendekatan kualitatif yaitu sebuah pendekatan yang berguna untuk menjelaskan fenomena sosial yang ingin diteliti secara mendalam. Penelitian kualitatif merupakan penelitian yang bermaksud untuk memahami fenomena tentang apa yang dialami oleh subjek penelitian misalnya perilaku persepsi, motivasi, tindakan, dan lainlain, secara holistik ${ }^{12}$ dan dengan cara deskripsi dalam bentuk kata-kata dan bahasa, pada suatu konteks khusus yang alamiah dan dengan memanfaatkan berbagai metode alamiah (dalam Moleong, 2004).

Penggunaan pendekatan dan tipe penelitian ini bertujuan agar peneliti bisa menjelaskan dan menggambarkan secara tertulis tentang fenomena yang peneliti angkat untuk disusun kedalam laporan penelitian yang kompleks dan efisien. Sehingga apa yang menjadi tujuan dari penelitian ini dapat terjawab dengan baik. Lokasi penelitian ini dilakukan di Nagari Sulit Air Kecamatan X Koto Diateh Kabupaten Solok. Unit analisis dalam penelitian ini adalah individu. Teknik pengumpulan data menggunakan wawancara, observasi dan dokumentasi sedangkan pemilihan informan menggunakan purposive

\footnotetext{
12 Holistik adalah sebuah cara pandang terhadap suatu yang dilakukan dengan konsep pengakuan bahwa hal keseluruhan adalah sebuah kesatuan yang lebih penting daripada bagian-bagian yang membentuknya. Kata holistik berasal dari bahasa inggris yang memiliki arti penekanan terhadap betapa pentingnya keseluruhan dan keterkaitan antara setiap bagian-bagian yang membentuknya.
} 
sampling. Teknik analisis data emik dan etik. Sedangkan untuk keabsahan data, peneliti menggunakan triangulasi sumber data.

\section{HASIL DAN PEMBAHASAN}

\section{Deskripsi Nagari Sulit Air}

Sejarah Nagari Sulit Air berdasarkan cerita dari orang tua-tua dan para pemangku adat kata atau kalimat Sulit Air berasal dari kata Coliek Aia yang merupakan kata kiasan berarti masyarakat harus mencontoh dan melihat sifat air. Sementara di beberapa tambo secara keselarasan sistem adat Minangkabau, Sulit Air merupakan ranah Cumeti Koto Piliang salah satu dari Langgam Nan Tujuah artinya sebelum berdirinya kerajaan Hindu - Budha di pulau andalas ada wilayah yang bernama Taraguang artinya jauh sebelum ini sudah ada kehidupan di ranah Sulit Air.

H. Rozali Usman Rangkayo Sutan dan Drs. Hamdullah Salim (1975) dalam Erwin Saman (2016) menceritakan tentang asal usul orang Sulit Air yang berawal dari kedatangan rombongan yang dipimpin oleh Dt. Mulo Nan Kawi dan Puti Anggo Ati dari Pariangan Padang Panjang ke Sulit Air pada sekitar abad ke-14. Pada perjalanan yang dilakukan oleh Dt. Mulo Nan Kawi dan rombongan sampai pada suatu lembah atau lurah di bawah Guok Taroguong, Koto Tuo mereka menemukan air yang keluar dari celah-celah batu yang mengalir ke anak sungai. Karena celah tempat air keluar tersebut sangat kecil, air seperti berdesakan untuk keluar sehingga terlihat sangat susah atau sulit keluar dari celah. Puti Anggo Ati mengatakan "ndee... suliknyo ayie kalua di batu o li". Dari kejadian alami itu lahirlah sebutan Sulit Air.

Nagari Sulit Air secara geografis berada pada 00 - 3' LS dan 100.280 BT (Gambar 1). Sulit Air juga merupakan salah satu Nagari terluas yang posisinya berada pada bagian utara Provinsi Sumatera Barat dengan ketinggian 500 - 750 Mdpl. Secara administratif pemerintahan Nagari Sulit Air berbatasan dengan:

- Utara $\quad$ : Batang ombilin dan Nagari Pasilihan

- Selatan : Nagari Tanjung Alai dan Nagari Tanjung Balit

- Timur : Kolok dan Talawi Sawahlunto

- Barat : Nagari Kacang, Simawang dan Nagari Bukik Kandung 
E-ISSN : 2721-3730

P-ISSN : 2656-5439

\section{Gambar 1. Peta Nagari Sulit Air}

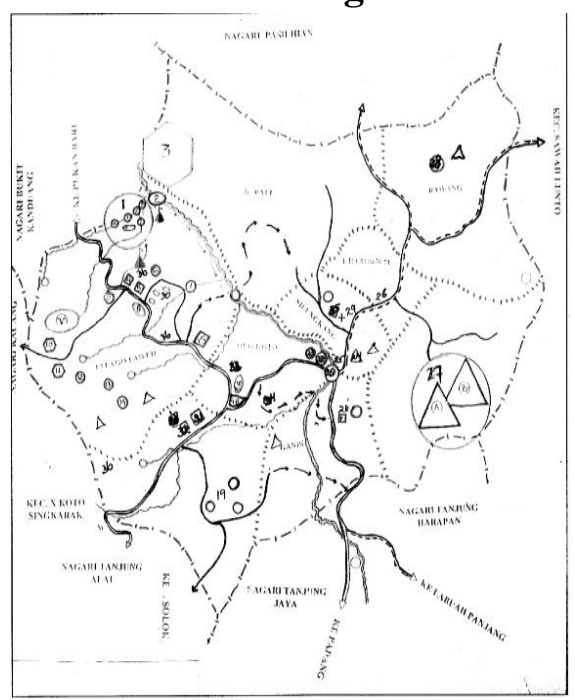

Sumber: Data Sekretaris Nagari Sulit Air Tahun 2019

\section{Profil Wali Nagari Sulit Air}

Nagari Sulit Air dipimpin oleh seorang Wali Nagari perempuan bernama Alex Suryani yang menjabat periode 2014 - 2020 (Gambar 2) yang merupakan sejarah untuk Nagari Sulit Air dipimpin oleh seorang perempuan. Alex Suryani yang akrab disapa Alex merupakan istri dari Firdaus Kahar yang juga menjadi Wali Nagari Sulit Air pada periode $2003-2006$.

\section{Gambar 2. Foto Wali Nagari Sulit Air}

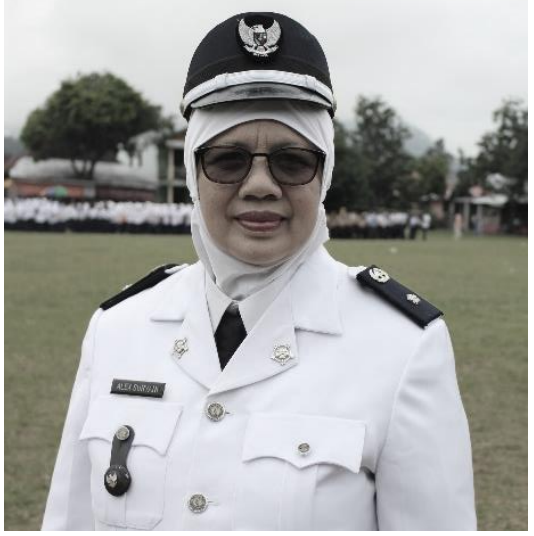

Sumber : Data Sekretaris Nagari Sulit Air 2019 
Alex Suryani lahir di Solok pada 11 November 1961 dan dibesarkan di Nagari Sulit Air tepatnya di Jorong Koto Gadang. Alex menamatkan Sekolah Dasar (SD) sampai Sekolah Menengah Pertama (SMP) di Nagari Sulit Air kemudian lanjut ke Sekolah Menengah Atas (SMA) swasta yang ada di Kota Padang yaitu DONBOSCO. Setelah itu Alex melanjutkan perkuliahan di Akademi Bahasa Asing (ABA) selama 3 tahun yang pada saat ini kita kenal dengan STBA Prayoga. Selepas perkuliahan Alex memutuskan untuk merantau ke Jakarta untuk mencari pekerjaan dimana dia pernah bekerja di perusahaan jepang sebagai operator untuk kontraktor dalam pembuatan peti kemas di Tanjung Priok, Alex sebagai Design Office untuk input data tentang akses proyek. Setelah satu tahun bekerja Alex pindah ke perusahaan Amerika sebagai Administrasi di perusahaan tersebut. Alex terus pindah-pindah perusahaan sampai akhirnya dia memutuskan untuk berhenti karena sedang hamil anak pertama.

Setelah melahirkan, Alex memutuskan untuk menyambung pendidikannya di STKIP PGRI Sumbar pada Tahun 1994. Pada saat kuliah di S1 Alex suka menjadi seorang instruktur di DSE yang bekerjasama dengan LAN (Lembaga Administrasi Negara). DSE adalah lembaga Jerman yang bekerja sama dengan Indonesia yang mempunyai program mencerdaskan orang-orang Indonesia bagian timur dengan tujuan membangun suatu daerah (Rural Development). Alex menamatkan kuliahnya pada tahun 1996 dan mengajar di salah satu SMA di Bangka Belitung karena suaminya bekerja di salah satu perusahaan timah di sana. Seiring berjalannya waktu, perusahaan suaminya mengalami kerugian dan mereka pulang ke Sulit Air. Tidak lama kemudian Alex merantau ke Batam untuk mengajar di sekolah Indo Global, setelah 1 tahun berjalan suami Alex terpilih menjadi Wali Nagari di Sulik Aia, kemudian Alex memutuskan untuk pulang ke kampung halaman.

\section{Gaya Kepemimpinan Wali Nagari Perempuan (Female Leadership) di Nagari Sulit Air Periode 2014 - 2020}

Eagly dan Johnson (dalam Peter, 2016) melakukan analisis gender dan gaya kepemimpinan yakni terdapat perbedaan jenis kelamin dalam gaya kepemimpinan maskulin untuk yang laki-laki dan gaya kepemimpinan feminism yang dimiliki perempuan. Eagly dan Johnson menyimpulkan gaya kepemimpinan perempuan lebih demokratik dibandingkan laki-laki dalam lingkungan organisasi yang sama. Di Sumatera Barat khususnya di Nagari Sulit Air kabupaten Solok peneliti menemukan adanya pemimpin perempuan sebagai Wali Nagari di Nagari tersebut. Pada pemilihan Wali Nagari yang dilakukan pada Tahun 2014 yang lalu menghasilkan sejarah baru bagi Nagari Sulit Air yaitu dengan terpilihnya seorang Wali Nagari perempuan pertama untuk memimpin Nagari tersebut dalam 6 Tahun kedepannya (2014 - 2020) yang sebelumnya selalu dipimpin oleh seorang laki-laki.

Sebagai seorang Wali Nagari tidak akan lepas dari kepemimpinan. Menurut Stephen P. Robbins (dalam Irham Fahmi, 2013) kepemimpinan adalah kemampuan untuk 
mempengaruhi suatu kelompok ke arah tercapainya tujuan. Berdasarkan penjelasan tersebut dalam mencapai suatu tujuan pemimpin harus bisa membaca situasi dan kondisi dari jajaran serta masyarakat yang menjadi tanggungannya dalam menjalankan tugas kepemimpinan sebagai Wali Nagari. Dalam perkembangan kepemimpinan, pendekatan yang paling diakui adalah pendekatan situasional yang dikembangkan oleh Hersey dan Blanchard. Kepemimpinan situasional berfokus pada kepemimpinan pada situasi di sekitar pemimpin. Prinsipnya adalah situasi yang berbeda menuntut jenis kepemimpinan yang berbeda. Dapat diketahui bahwa untuk menjadi pemimpin yang efektif harus menyesuaikan gaya dengan tuntutan dari situasi yang berbeda.

Kepemimpinan situasional menekankan bahwa kepemimpinan terdiri dari dimensi perintah dan pemberian dukungan, masing-masing dimensi itu diterapkan pada situasi tertentu. Untuk menentukan apa yang diperlukan untuk situasi tertentu pemimpin harus mengevaluasi dan menilai karyawannya dalam melaksanakan tugas yang diberikan. Keterampilan dan motivasi karyawan sangat beragam, kepemimpinan situasional harus mengubah tingkatan di mana memberi perintah atau dukungan agar sesuai dengan kebutuhan pengikut yang berubah-ubah. Pemimpin yang efektif adalah mereka yang bisa mengetahui apa yang dibutuhkan karyawan, serta menyesuaikan gaya mereka untuk bisa memenuhi kebutuhan itu.

Dalam melihat gaya kepemimpinan yang dilakukan oleh Wali Nagari Sulit Air peneliti menggunakan pendekatan situasional. Gaya kepemimpinan itu merupakan pola perilaku dari seseorang atau individu yang mencoba mempengaruhi orang lain untuk mencapai suatu tujuan yang mencakup perilaku perintah (tugas) dan perilaku pemberi dukungan (hubungan). Gaya kepemimpinan tersebut bisa dikelompokkan dalam empat kategori yang berbeda seperti (1). Gaya Memerintah (SI), (2). Pendekatan Pelatihan (SII), (3). Pendekatan Mendukung (SIII) dan (4). Pendekatan Mendelegasikan (SIV).

\section{- Gaya Memerintah dan Pendekatan Pelatihan}

Pada gaya memerintah ini pemimpin memfokuskan komunikasi pada pencapaian tujuan dan menghabiskan jumlah waktu yang sedikit dengan menggunakan perilaku memberikan dukungan dengan begitu pemimpin memberikan instruksi tentang apa dan bagaimana tujuan yang akan dicapai oleh pengikut dan mengawasi mereka dengan hati-hati. Dilihat dari gaya kepemimpinan situasional gaya pertama (SI) untuk menghadapi tingkat perkembangan karyawan/staf D1. Dalam situasi ini karyawan/staf belum mampu dan mau sehingga memerlukan pengarahan yang tegas berupa instruksi untuk melakukan tugas dalam 
mencapai tujuan. Dari hasil wawancara yang dilakukan dengan ketua BMN (Badan Musyawarah Nagari) Tasrial mengatakan $:^{13}$

....tantu yang namonyo Wali Nagari melakukan sesuatu tu sesuai dengan tujuan dia dulu, yang di rancang dalam bentuk programnyo, kalau nio jadi Wali Nagari punyo progam seperti ini, kemudian program itu dalam bentuk RPJM yang dilakukan bermusyawarah dengan masyarakat....

.....tentu yang Namanya Wali Nagari melakukan sesuatu itu sesuai dengan tujan pertama dia. Yang dirancang dalam bentuk program dia, kalau mau jadi Wali Nagari punyo program seperti ini, kemudia program tersebut di bentuk dalam RPJM yang dilakukan bermusyawarah dengan masyarakat...

Dalam menghadapi karyawan/staf yang baru saja bekerja di kantor Wali Nagari, Alex sebagai pemimpin memberikan tugas kepada karyawan/staf sesuai dengan tujuan yang akan dicapai. Kemudian dikuatkan oleh Meri Aswita selaku sekretaris nagari yang mengatakan bahwa : ${ }^{14}$

....contohnyo sajo dalam penyelesaian masalah buk wali kok dapek tujuan partamo tu yo harus tacapai.....

....contohnya saja dalam penyelesaian masalah, ibu Wali selalu menjadikan tujuan pertama itu harus tercapai......

Dari hasil wawancara tersebut kita dapat mengetahui bahwa untuk mencapai suatu tujuan Wali Nagari Sulit Air memberikan instruksi kepada setiap karyawan/staf dalam mencapai program-program yang sudah dirancang pada awal masa pemerintahan Wali Nagari. Selain berfokus pada tujuan Alex juga berfikir untuk kemajuan dari karyawan/staff yang baru seperti kutipan wawancara yang peneliti lakukan dengan Wali Nagari yang mengatakan $:^{15}$

......dari dana desa ada anggaran untuk melakukan pelatihan seperti pelatihan untuk bagaimana bekerja pada suatu bidang seperti bendahara, sekretaris, pelayanan dan lain sebagainya. Nanti kita akan mengirim karyawan/staf tersebut berdasarkan permintaan dari pihak yang menyelenggarakan. Pelatihan tersebut ada di berbagai daerah, jadi dari dana desa tersebut kita fasilitasi yang tujuannnya untuk meningkatkan kapasitas aparat aparatur nagari.....

Dari kutipan wawancara dengan Alex, peneliti melihat bahwa adanya perhatian yang dilakukan oleh Alex sebagai pemimpin kepada karyawan/staf yang sebenarnya tidak dilakukan pada tahapan pertama pendekatan situasional yang dikembangkan oleh Hersey dan

13 Berdasrkan Wawancara Peneliti dengan Tasrial BA Selaku Ketua BMN (Badan Musyawarah Nagari) Sulit Air di Madrasah Tsanawiyah Muhammadiyah Swasta di Nagari Sulit Air Kecamatan X Koto DIateh Kabupaten Solok Pada Tanggal 10 September 2019

14 Berdasarkan Wawancara Peneliti dengan Meri Aswita Selaku Sekretaris Nagari Sulit Air di Kantor Wali Nagari, Nagari Sulit Air, Kecamatan X Koto DIateh, Kabupaten Solok Pada Tanggal 28 Agustus 2019

15 Berdasarkan Wawancara Peneliti dengan Alex Suryani Selaku Wali Nagari Sulit Air di Kantor Wali Nagari, Nagari Sulit Air, Kecamatan X Koto Diateh, Kabupaten Solok Pada Tanggal 28 Agustus 2019 
Blanchard. Pada tahapan pertama pendekatan situasional ini seharusnya pemimpin memfokuskan komunikasi pada pencapaian tujuan dengan pemberian dukungan yang sedikit. Berbeda dengan tahapan kedua pada pendekatan ini, dimana perintah dan pemberian dukungan yang tinggi dilakukan oleh pemimpin kepada karyawan/stafnya.

Dalam pendekatan pelatihan atau pendekatan kedua pada teori yang dikembangkan oleh Hersey dan Blanchard pemimpin memfokuskan komunikasinya pada pencapaian tujuan dan pemenuhan kebutuhan sosial-emosi pengikut. Selain pelatihan untuk karyawan/staf Alex juga menyediakan atau memfasilitasi pelatihan-pelatihan untuk masyarakat agar masyarakat juga bisa menikmati dan mengembangkan bakat mereka dalam segala bidang seperti yang diungkapkan oleh Ratna Dewi sebagai seorang masyarakat di Nagari Sulit Air: ${ }^{16}$

....kalau pelatihan itu ocok, tapi awak kadang indak tibo, kadang apo nan di latih tu di di tandiangan lo bia menumbuhkan dan mambukak pangana dari masyarakat lain supayo ikuik berkontribusi dalam pelatihan-pelatihan yang di adoan dek Nagari....

.....pelatihan-pelatihan itu sering, tapi saya terkadang tidak bisa hadir, biasanya apa yang di berikan pelatihan itu di pertandingkan biar bisa menumbuhkan dan membuka fikiran dari masyarakat lain supaya ikut berkontribusi dalam pelatihan-pelatihan yang di adakan oleh Nagari......

Dari hasil wawancara tersebut peneliti menemukan bahwa ada pengawasan yang dilakukan oleh Wali Nagari terhadap karyawan/staf yang menjadi tanggung jawab dalam melaksanakan tugas. Wali Nagari Sulit Air selalu berupaya untuk meningkatkan kualitas SDM (Sumber Daya Manusia) karyawan/staf, masyarakat dan organisasi-organisasi masyarakat demi tercapainya tujuan yang sudah diatur pada saat awal pemerintahan. Namun pada saat peneliti di lapangan menemukan bahwa Alex Suryani sebagai Wali Nagari tidak ada membedakan antara gaya memerintah dengan pendekatan pelatihan dimana seharusnya ada perbedaan-perbedaan yang dilakukan kepada karyawan/staf dan masyarakat.

\section{- Pendekatan Mendukung}

Pemimpin tidak hanya fokus pada tujuan, tetapi menggunakan gaya pemberian dukungan yang membuat karyawan menunjukan keterampilan dalam melaksanakan tugas yang sudah ditetapkan. Pada gaya mendukung ini mencakup mendengarkan, memuji, meminta masukan, dan memberi umpan balik. Gaya ini tepat digunakan pada karyawan/staf yang tingkat kesiapan sedang ke tinggi (DIII). Hal ini disebabkan kemampuan sudah ada tetapi kemauan belum. Oleh karena itu, dalam rangka mendorong supaya karyawan/staf termotivasi untuk melakukan tugas, diperlukan komunikasi dua arah yang intensif antara

\footnotetext{
16 Berdasarkan Wawancara Peneliti dengan Ratna Dewi Selaku Masyarakat Nagari Sulit Air di Samping Kantor Wali Nagari, Nagari Sulit Air, Kecamatan X Koto Diateh, Kabupaten Solok Pada Tanggal 10 September 2019
} 
pemimpin dan karyawan/staf untuk memotivasinya. Seperti ungkapan dari Alex pada peneliti saat melakukan wawancara yaitu $:^{17}$

......lembaga-lembaga yang ada di Sulit Air banyak yang punya keterempilan, ibu kasih anggaran, masing-masing lembaga tersebut bebas untuk mengembangkan keterampilan sesuai dengan apa yang mereka mau tapi terkadang SDM kita terbatas, mereka tidak mampu padahal dari nagari sudah memfasilitasi.....

Wali Nagari menyediakan fasilitas untuk masyarakat yang mempunyai kreatifitas untuk mengembangkan potensinya dalam bentuk anggaran. Tetapi masyarakat masih belum memanfaatkan apa yang diberikan oleh Wali Nagari karena masih kurangnya tingkat partisipasi dari masyarakat yang ada di Nagari Sulit Air. Ungkapan dari Wali Nagari tentang adanya anggaran dan pelatihan yang diberikan kepada masyarakat dibenarkan oleh Ramainur yang mengatakan: ${ }^{18}$

.....sabananyo pelatihan-pelatihan tu cukuik di berikan oleh Nagari, cuma tidak berjalan, tidak berjalan tu karano warga ko masing-masing indak namuah, jadi indak bajalan. Itu indak kesalahan dari nagari tapi kesalahan dari masyarakat sendiri. Urang Sulik Aia ko susah, nyo jiwa-jiwa pedagang sadonyo, kalau urang kampuang yo bisa diatur kalau Sulik Aia indak namuah do, kapalo kore sadonyo.....

......sebenarnya pelatihan-pelatihan itu cukup di berikan oleh Nagari, cuma tidak berjalan sesuai dengan apa yang sebenarnya, tidak berjalan itu karena masyarakat masing-masing itu tidak mau sehingga tidak berjalan. Itu bukanlah kesalahan dari Nagari tetapi kesalahan dari masyarakat itu sendiri. Orang Sulit Air ini susah, mereka memiliki jiwa pedagang semuanya, kalau orang kampung bisa diatur berbeda dengan Sulit Air mereka tidak bisa diatur, mereka keras kepala.....

Berdasarkan wawancara yang dilakukan oleh peneliti dengan berbagai informan yang ada di Nagari Sulit Air tersebut memang mereka mengatakan bahwasanya Wali Nagari sangat mendukung terhadap apa potensi-potensi yang ada pada karyawan/staf, masyarakat, lembaga dan sebagainya di lingkungan yang menjadi tanggung jawab Wali Nagari Sulit Air tanpa ada perbedaan-perbedaan yang bisa memunculkan konflik.

\section{- Pendekatan Mendelegasikan}

Pemimpin menawarkan lebih sedikit masukan tugas dan dukungan sosial, meningkatkan motivasi dan keyakinan diri karyawan/staf dalam kaitannya dengan tugas. Pemimpin yang menggunakan pendekatan delegasi ini mengurangi keterlibatan dirinya dalam perencanaan, pengawasan hal-hal yang rinci dan klarifikasi tujuan. Gaya ini tepat dilakukan pada karyawan/staf yang tingkat kesiapannya tinggi (DIV). Hal ini disebabkan

\footnotetext{
17 Berdasarkan Wawancara Peneliti dengan Alex Suryani Selaku Wali Nagari Sulit Air di Kantor Wali Nagari, Nagari Sulit Air, Kecamatan X Koto Diateh, Kabupaten Solok Pada Tanggal 28 Agustus 2019

18 Berdasarkan Wawancara Peneliti dengan Ramainur Selaku Ketua Jorong Silungkang Nagari Sulit Air di Kantor Wali Nagari, Nagari Sulit Air, Kecamatan X Koto Diateh, Kabupaten Solok Pada Tanggal 28 Agustus 2019
} 
karena karyawan/staf sudah mampu melaksanakan tugasnya sehingga tidak diperlukan lagi pengarahan dan sudah memiliki kemauan sehingga tidak perlu melakukan hubungan manusia yang tinggi untuk memotivasi.

Gaya keempat dalam pendekatan situasional memang di praktekan oleh Wali Nagari dalam memimpin, seperti dalam kutipan wawancara peneliti dengan Muslim yang mengatakan bahwa $;{ }^{19}$

.....di dalam struktur Wali Nagari kan banyak pembagiannyo tu, ado sekretarisnyo, bendahara, kepala-kepala bidang dan jajaran, disitu Wali Nagari alah mambagi tugas ka bawahannyo. Beliau menginstruksikan itu memang apo yang kito karajoan, umpamonyo masalah pembangunan jalan, beko ado kasi pembangunan yang mengontrol pekerjaan tu, skali-skali beko baru buk wali pai mancaliak ka lokasi tapi yang bertanggung jawab dalam pembangunan tu tantu kasi pembangunan.....

......di dalam struktur Wali Nagari ada banyak pembagian seperti, sekretaris, bendahara kepala-kepala bidang dan jajaran disana Wali Nagari sudah membagi tugas terhadap karyawan/stafnya. Dia menginstruksikan itu memang berdasarkan apa yang kita kerjakan, seperti masalah pembangunan jalan, nanti ada kasi pembangunan yang mengontrol pekerjaan itu, skali-skali nanti baru dia pergi melihat perkembangan ke lokasi tapi yang bertanggung jawab dalam pembangunan itu tentu kasi pembangunan.....

Dari temuan peneliti dilapangan mendapatkan bahwa Alex sebagai Wali Nagari sudah menggunakan pendekatan mendelegasikan secara baik, karena Alex sudah melihat dan memperhatikan siapa yang pantas untuk menduduki jabatan tertentu yang kemudian dia percayai untuk mengawasi tingkatan yang ada pada jajaran dibawahnya. Seperti yang diungkapkan oleh Muslim, dalam hal pembangunan di Nagari ada karyawan/staf Nagari yang mengawasi jalanya pembangunan tersebut seperti Ka.Si Pembangunan yang sudah di berikan tugas dan tanggung jawab oleh Wali Nagari. Kemudian Meri sebagai sekretaris Nagari menambahkan bahwa mereka selalu ada laporan yang akan diberikan kepada Wali Nagari sebagai bentuk pertanggungjawaban terhadap apa yang sudah mereka kerjakan selama satu bulan.

Pendekatan situasional yang di kembangkan oleh Hersey dan Blanchard yang digunakan oleh peneliti dalam melihat gaya kepemimpinan Wali Nagari Sulit Air mendapatkan bahwa ada tiga gaya dan pendekatan yang dilakukan oleh Wali Nagari terhadap karyawan/staf dan masyarakat (Bagan 2). Tapi ada dua gaya dan pendekatan yang digabungkan menjadi satu oleh Wali Nagari tersebut karena peneliti tidak ada menemukan perbedaan tindakan yang dilakukan oleh Wali Nagari terhadap karyawan/staf dan masyarakat pada situasi yang seharusnya berbeda. Sehingga peneliti hanya menemukan pendekatan

\footnotetext{
19 Berdasarkan Wawancara Peneliti dengan Muslim Selaku Ketua Jorong Taram Nagari Sulit Air di Kantor Wali
} Nagari, Nagari Sulit Air, Kecamatan X Koto Diateh, Kabupaten Solok Pada Tanggal 29 Agustus 2019 
pelatihan, pendekatan mendukung dan pendekatan mendelegasikan. Sedangkan gaya memerintah disamakan oleh Wali Nagari Sulit Air kedalam pendekatan pelatihan dimana antara gaya memerintah dan pendekatan pelatihan terdapat perbedaan walau hanya sedikit.

\section{Bagan 2. Kepemimpinan Wali Nagari Sulit Air}

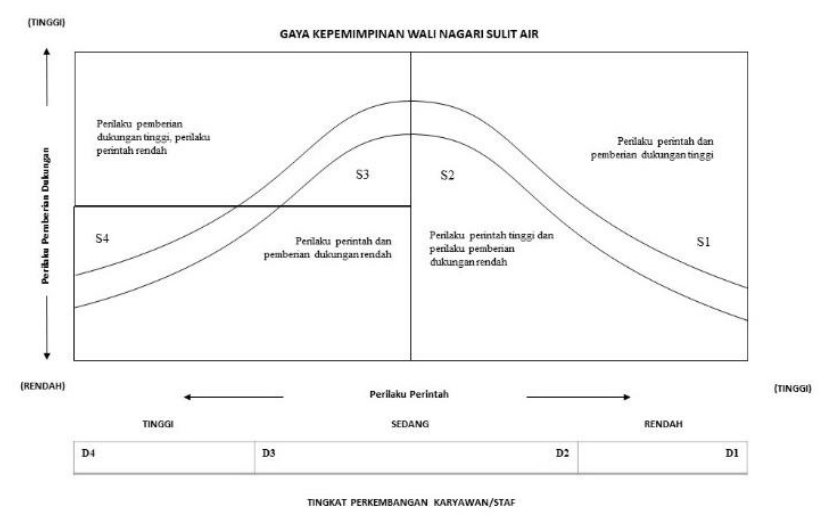

Sumber : Diolah Peneliti Tahun 2019

\section{KESIMPULAN}

Kepemimpinan adalah kemampuan untuk mempengaruhi suatu kelompok ke arah tercapainya tujuan. Pemimpin mampu mempengaruhi perilaku orang lain tanpa harus mengandalkan kekerasan, sebagai seorang pemimpin harus bisa bersikap sesuai dengan situasi yang ada disekitar pemimpin tersebut. Seperti pendekatan situasional yang dikembangkan oleh Hersey dan Blanchard serta perbedaan gender dalam kepemimpinan perempuan (Female Leadership) dengan kepemimpinan laki-laki yang dikembangkan oleh Eagly \& Carli yang ada di Nagari Sulit Air.

Dalam melihat gaya kepemimpinan Wali Nagari Sulit Air periode 2014 - 2020 dengan menggunakan pendekatan situasional didapatkan bahwa ada tiga gaya dan pendekatan yang diterapkan Wali Nagari untuk menghadapi karyawan/staf, masyarakat dan lain sebagainya. Dari pendekatan situasional yang dikembangkan oleh Hersey dan Blanchard terdapat empat gaya dan pendekatan, tetapi Wali Nagari Sulit Air menggabungkan dua gaya dan pendekatan menjadi satu, sehingga gaya kepemimpinan Wali Nagari Sulit Air dalam penelitian ini hanya menemukan gaya memerintah yang digabungkan dengan pendekatan pelatihan, pendekatan mendukung dan pendekatan mendelegasikan. 


\section{DAFTAR PUSTAKA}

A.Rauf, Muhammad. (2016). Politik Hukum Pembentukan Desa Adat Dalam Sistem Pemerintahan di Indonesia. Jurnal De Lega Lata. Vol. I No. 2 Th. 2016

Badeni. 2013. Kepemimpinan \& Perilaku Organisasi. Bandung: Alfabeta, cv

Fahmi, Irham. 2013. Manajemen Kepemimpinan Teori \& Aplikasi. Bandung: Alfabeta, cv

Facebook.com penelusuran tentang berita penganggkatan Wali Nagari Sulit Air yang dilihat pada (https://www.facebook.com /permalink.php?id= 216719908184 \&story_fbid=10152878406538185)

GoogleMap.com penelusuran peta nagari sulit air di akses pada (Sumber:https://www.google.com/maps/place/Sulit+Air,+X+Koto+Diatas,+Solok,+S umatera+Barat/)

Hadler, Jeffrey. 2010. Sengketa Tiada Putus: Matriarkat, Reformisme Agama dan Kolonialisme di Minangkabau. Jakarta: Freedom Institute

Hasan, Firman. 1988. Dinamika Masyarakat dan Adat Minangkabau. Padang: Pusat Penelitian Universitas Andalas.

Hidayat, Yayan dan Iwan I. Febrianto. 2016. Transformasi dan Dampak Dualisme Kelembagaan dalam Pemerintah Adat Minang: Studi Terhadap Nagari Pariangan, Tanah Datar, Sumatera Barat.

Irawati. 2010. Bundo Kanduang dan Tantangan Politik dalam Badan Perwakilan Anak Nagari (BPAN). Jurnal Demokrasi. Vol. IX No. 1 Th. 2010

Iskandar, Israr. 2012. Wali Nagari Perempuan di Era Reformasi: Studi Kasus Terpilihnya Wali Nagari Batu Basa Kecamatan Pariangan Kabupaten Tanah Datar Tahun 2009. Jurnal Aspirasi. Vol. 2 No. 1 Th. 2011

Jendrius. 2011. Ayam Batino Lah Bakukuak : Otonomi Daerah dan Keterlibatan Perempuan dalam Pemerintahan Nagari di Sumatera Barat. Jurnal Ilmiah Kajian Gender

Jendrius. 2017. Women In Minangkabau Nagari Government. Padang: CV. Rumahkayu Pustaka Utama

Latief, M Syahbudin. 2000. Persaingan Calon Kepala Desa di Jawa. Yogyakarta: Media Pressindo

LKAAM. 2002. Adat Basandi Syarak, Syarak Basandi Kitabullah. Padang: Sako Batuah.

Moleong Lexy J. 2004. Metodologi Penelitian Kualitatif. Bandung: PT. Remaja Rosdakarya. 
Northouse, Peter G. 2016. Kepemimpinan: Teori dan Praktik, Edisi Keenam. Jakarta: Indeks Permata Puri Media

Sashkin, Marshall \& Molly G. Sashkin. 2011. Prinsip-Prinsip Kepemimpinan. Jakarta: PT Gelora Aksara Pratama

Yunus, Yasril. 2013. Aktor Kultural Dalam Pemerintahan Terendah Di Sumatera Barat (Posisi Ninik Mamak Dalam Struktur Adat dan Penyelenggaraan Pemerintahan Formal). Jurnal Humanis. Vol. XII No. 1 Th. 2013 